\title{
Prevalence of Listeria monocytogenes in European cheeses - A systematic review and
} meta-analysis

\author{
Martinez Rios, Veronica; Dalgaard, Paw
}

Published in:

Food Control

Link to article, DOI:

10.1016/j.foodcont.2017.07.020

Publication date:

2018

Document Version

Peer reviewed version

Link back to DTU Orbit

Citation (APA):

Martinez Rios, V., \& Dalgaard, P. (2018). Prevalence of Listeria monocytogenes in European cheeses - A

systematic review and meta-analysis. Food Control, 84, 205-214. https://doi.org/10.1016/j.foodcont.2017.07.020

\section{General rights}

Copyright and moral rights for the publications made accessible in the public portal are retained by the authors and/or other copyright owners and it is a condition of accessing publications that users recognise and abide by the legal requirements associated with these rights.

- Users may download and print one copy of any publication from the public portal for the purpose of private study or research.

- You may not further distribute the material or use it for any profit-making activity or commercial gain

- You may freely distribute the URL identifying the publication in the public portal 
1 Prevalence of Listeria monocytogenes in European cheeses: A systematic review and meta-analysis

2 Veronica Martinez-Rios*, Paw Dalgaard

3

$4 \quad$ National Food Institute (DTUFood), Technical University of Denmark, Kgs. Lyngby, Denmark

5

6

7

8

9

10

11

* Corresponding author: Analytical and Predictive Microbiology, National Food Institute, Technical

12 University of Denmark, Kemitorvet, Building 204, DK-2800, Kgs. Lyngby, Denmark. E-mail:

13 veri@,food.dtu.dk (V. Martinez-Rios)

14

15

16

17

18

19 


\section{ABSTRACT}

Both in Europe and worldwide cheese has caused important outbreaks of listeriosis and can be a vehicle for transmission of Listeria monocytogenes to consumers. A systematic review and metaanalysis were conducted using scientific literature and European Food Safety Authority (EFSA) reports to summarize available data on the prevalence of L. monocytogenes in different types of cheeses produced in Europe. Meta-analysis models were used to estimate mean prevalence of the pathogen and to compare prevalence among types of cheeses (fresh, ripened, veined, smear and brined) and cheeses produced using, respectively, pasteurized or un-pasteurized milk. Data from a total of 130,604 samples were analysed. Mean prevalence for presence during 2005-2015 estimated from scientific literature (2.3\% with confidence interval (CI): $1.4-3.8 \%)$ was more than three times higher than results from EFSA reports $(0.7 \%$; CI: $0.5-1.1 \%)$. The prevalence differed among types of cheeses including fresh (0.8\%; CI: $0.3-1.9 \%)$, ripened $(2.0 \%$; CI: $0.8-4.9 \%)$, veined $(2.4 \%$; CI: 0.9-6.3\%), smear (5.1\%; CI: 1.9-13.1\%) and brined (11.8\%; CI: 3.5-33.3\%). Mean prevalence of $L$. monocytogenes in soft/semi-soft cheeses were not significantly different $(\mathrm{P}>0.05)$ for cheeses produced from pasteurized (0.9\%; CI: $0.4-1.9 \%)$ or un-pasteurized (1.0\%; CI: 0.4-2.2\%) milk. For cheese samples reported by EFSA $0.2 \%$ CI: $0.1-0.4 \%$ had concentration of L. monocytogenes above the critical European limits of $100 \mathrm{cfu} / \mathrm{g}$. In addition, this systematic review focused on groups/species of microorganisms suitable as indicator organisms for L. monocytogenes in cheeses to reflect the level of production hygiene or as index organisms to assess the prevalence of $L$. monocytogenes in cheeses. However, no suitable indicator or index organisms were identified. The performed meta-analyses improved our understanding of L. monocytogenes prevalence in different types of cheeses and provided results that can be useful as input for quantitative microbiological risk assessment modelling.

Keywords: Occurrence, fresh cheese, soft and semi-soft cheeses, risk assessment 


\section{Introduction}

The genus Listeria includes more than 20 species that can be divided into three clades (Weller et al. 2015). Two Listeria species belonging to the same clade are generally considered to be pathogenic, L. monocytogenes in humans and L. ivanovii in other mammals. Nevertheless, there have been some reports of $L$. seeligeri and L. ivanovii causing illness in humans (Cummins et al., 1994; Rocourt et al., 1986). The likelihood of L. monocytogenes infection leading to listeriosis is greatest among certain groups; including pregnant woman, neonates, immunocompromised adults and the elderly (Ryser \& Marth, 2007). Within the European Union (EU) there has been a statistically significant increasing trend of listeriosis over the period 2009-2015. Specifically, the numbers of confirmed human cases of listeriosis were 1,331 and 2,206 in 2009 and 2015, respectively (EFSA, 2016). A total of 270 deaths due to listeriosis were reported within nineteen EU member states. The overall EU notification rate of listeriosis was 0.46 cases per 100.000 population with a case-fatality rate of 17.7\% (EFSA, 2016). Seven EU Member States and Norway provided information from conventional serotyping of L. monocytogenes (accounting for $23.3 \%$ of all confirmed cases). The most common serotypes in 2013 were $1 / 2 \mathrm{a}(57.5 \%)$ and $4 \mathrm{~b}(34.3 \%)$, followed by $1 / 2 b(6.4 \%), 1 / 2 c(1.4 \%), 3 a$ and $3 b$ (both $0.2 \%)$ (EFSA, 2015).

In 2010-2011 an EU baseline survey (EFSA, 2013a) collected data about presence of $L$. monocytogenes and the non-compliance for different ready-to-eat (RTE) food categories at retail. The proportion of L. monocytogenes positive samples at retail was highest in fish products (mainly smoked fish), followed by soft and semi-soft cheeses and RTE meat products. Specifically, the EU prevalence of $L$. monocytogenes in cheeses at retail was $0.47 \%$ (CI: $0.29-0.77 \%$ ) determined as 16 positive samples out of 3393 at the end of shelf-life. For these 2010-2011 samples $0.06 \%$ (CI: 0.02$0.24 \%$ ) determined as two samples out of 3393 exceeded the critical concentration of $100 \mathrm{cfu} / \mathrm{g}$ 
(EFSA, 2013a). In 2015 fifteen samples out of 3039 exceeded the critical concentration of $100 \mathrm{cfu} / \mathrm{g}$ (EFSA, 2016).

The first reported outbreak of human listeriosis associated with consumption of cheese occurred in the USA during 1985 (Linnan et al., 1988) and was caused by a fresh cheese. Since then, several outbreaks associated with consumption of cheese have occurred worldwide and fatalities continue to be reported (Table 1). Clearly, it is important to collect information and to analyse data in an attempt to improve our understanding and options to better manage this risk.

Meta-analysis is a statistical approach that can be used to analyse, for example, prevalence data (effect size) originating from various sources (primary studies) and in this way provide an overview of effects and variability (Glass, 1976; Sutton, et al., 2001). Lately, meta-analysis has been used to study several food safety issues and the quantitative results obtained can been used as inputs in risk assessment models (Baron et al., 2009).

Fortunately, prevalence and concentrations of L. monocytogenes in cheeses and cheese processing environments are low. Therefore, to evaluate its potential presence other index or indicator microorganisms that are easier to determine or quantify can be relevant to analyse. Index organisms can be used to assess likelihood of the presence of a pathogen whereas indicator organisms demonstrate a failure in Good Hygiene Practices (GHP) (Brodsky, 1995; Mossel, 1978). EU Regulation (EC) No 2073/2005 use coagulase-positive staphylococci as index organisms to assess the likelihood of staphylococcal enterotoxins in cheese made from raw or pasteurized milk and $E$. coli is used as an indicator for the level of production hygiene in cheese made from milk that has undergone heat treatment. Furthermore, Listeria spp. has been used as index organisms for the likely presence of L. monocytogenes in food (FSIS, 2014; Gilbert et al., 2000). 
The objective of the present study was to perform a systematic review and a meta-analysis of the prevalence of L. monocytogenes in different types of European cheeses and study potential indicator organisms for assessment of production hygiene or index organisms for implementation in the assessment of product safety.

\section{Materials and methods}

\subsection{Literature search and inclusion criteria}

A systematic review was performed following the protocol presented by Sargeant et al., 2005. Literature searches were carried out to identify suitable scientific literature using Web of Science (2017) or DTU Findit (2017) databases for papers indexed since 1985 as well as Google searches using English, French, Italian, and Spanish terms for combinations of Listeria spp., $L$. monocytogenes, cheese, dairy, prevalence, incidence and occurrence. Electronic searches were carried out to identify reports of the prevalence for Listeria spp. in cheese. This included reports by national and international organizations such as World Health Organization (WHO), EFSA and the International Commission for Microbiological Specification in Foods (ICMSF).

For inclusion in the meta-analysis results had to meet three requirements: (i) to come from original studies, (ii) to be obtained by using approved (FDA/FIL-IDF or ISO) microbiological methods for detection of Listeria spp. and (iii) originate from cheeses produced in Europe during the period of 2005 to 2015 .

\subsection{Data and definitions}

Cheese-type definitions were necessary in order to categorize studies from scientific literature. Available information allowed for a classification based in maturation characteristics. For 
the purpose of this paper, the following definitions apply. Fresh cheeses are curd-style cheeses which do not undergo any ripening (CAC, 2013), for example, queso fresco, cottage cheese, Mozzarella or Ricotta. Ripened cheeses are not ready for consumption shortly after manufacture and maturation is needed for development of specific cheese characteristics (CAC, 2013), for example, Gouda, Edam, Cheddar or Parmesan. Veined cheeses are ripened cheeses in which ripening has been accomplished primarily by the development of the mould Penicillum roqueforti throughout the interior and/or on the surface, for example, Roquefort, Gorgonzola, Cabrales, Stilton or Danablu. Smear cheeses are ripened cheeses where the surface is treated with Penicillum candidum, Penicillum camemberti or Brevibacterium linens, for example, Brie, Camembert, Limburger or Taleggio. Brined cheeses are ripened and stored in brine until they are sold or packed, for example, Feta or Ricotta salata (Fox et al., 2000).

Classification of cheese in EFSA reports are based on cheese moisture content. Soft-cheeses have a percentage of moisture, on a fat-free basis, higher than $67 \%$. Semi-soft cheeses have 62 to $67 \%$ fat-free moisture and are characterized by their firm but elastic feel. Hard cheeses have 49 to $56 \%$ fat-free moisture (CAC, 2013; EFSA, 2013b).

\subsection{Problem statement}

To estimate prevalence of $L$. monocytogenes in cheese during the period 2005-2015 (i) from scientific literature data, (ii) from data in EFSA reports, (iii) from scientific literature and data in EFSA reports when combined and (iv) to study groups/species of microorganisms suitable as indicator or index organisms to assess prevalence of L. monocytogenes in cheeses.

\subsection{Description of data sets for meta-analysis and regression modelling}

From each primary study the number of samples positive for L. monocytogenes $(s)$ and the total number of samples $(n)$ were extracted. Information about year of survey, country, sample 

weight and information on sampling at production site or at retail were also collected from each primary study. Meta-analysis for prevalence of L. monocytogenes in cheese as reported in the scientific literature was based on 17 primary studies including a total of 7,221 samples (Table 2), while data from seven EFSA reports with a total of 123,383 samples were included (Table 3 and Table 4). The regression model used to evaluate indicator/index organisms for L. monocytogenes in European cheeses was based in 16 primary studies all from the scientific literature and including a total of 3,852 samples (Table 5).

\subsection{Meta-analysis}

$$
\text { Prevalence }\left(p_{i}=s_{i} / n_{i}\right) \text { data was studied as observed effect size }\left(\theta_{i}\right) \text { and they were logit }
$$

transformed in order to restrict values to a range between $0-1$ and to stabilize variance (Eq. 1;

Viechtbauer, 2010). The parameter measuring effect size $\left(\theta_{i}\right)$ is a common metric that permits direct comparison and summation of primary studies (Borestein et al., 2009).

$\theta_{i}=\operatorname{logit} p_{i}=\ln \left(\frac{p_{i}}{1-p_{i}}\right)=\ln \left(\frac{s_{i}}{n_{i}-s_{i}}\right)$

Models with random-effects were used to calculate prevalence values (mean and 95\% CI) of $L$. monocytogenes across primary studies (Eq. 2; Borestein et al., 2009):

$$
T_{i}=\theta_{i}+\varepsilon_{i}=\mu+u_{i}+\varepsilon_{i}
$$

where $T_{i}$ is the true effect size for each primary study $(i=1,2, \ldots), \varepsilon_{i}$ is the sampling error and $\mu$ is the mean true effect size. $u_{i}$ represents the true variation in effect sizes being compose of withinstudy $\left(\sigma^{2}\right)$ and between-study variance $\left(\tau^{2}\right)$.

The between-study variance $\left(\tau^{2}\right)$ is estimated from the Q-statistic (DerSimonian \& Laird 1986), 
$154 \quad \hat{\tau}^{2}=\left\{\begin{array}{c}\frac{Q-(k-1)}{\sum w_{i}-\frac{\sum w_{i}^{2}}{\Sigma w_{i}}}, \text { for } Q>(k-1) \\ 0, \text { for } Q \leq(k-1)\end{array}\right.$

155 where Q is calculated by Eq. 4 and $5, k$ is the number of studies and $w_{i}$ the weight assigned to each 156 study (Eq.5).

$157 \quad Q=\sum w_{i}\left(T_{i}-\mu\right)^{2}$

$158 \mu=\frac{\sum_{i} w_{i} T_{i}}{\sum_{i} w_{i}}$

$159 \quad w_{i}=\frac{1}{\sigma_{i}^{2}+\tau_{i}^{2}}$

A significant value of the Q-statistic indicates a real effect difference between primary

161 studies and suggests the use of a multilevel model (Xabier et al., 2014). The $I^{2}$ index was used to

162 measure the extent of between-study variance dividing the difference between the result of the $Q$ -

163 statistic and its degrees of freedom $(k-1)$ by the $Q$ value itself, and then multiply by 100 . Higgins

$164 \&$ Thompson (2002) proposed a classification of $I^{2}$ values with percentages of around $25 \%\left(I^{2}\right.$

$165=25), 50 \%\left(I^{2}=50\right)$ and $75 \%\left(I^{2}=75\right)$ corresponding to low, medium and high between-study

166 variance, respectively. The $\tau^{2}$ and $I^{2}$ indices are related and higher $\tau^{2}$ values corresponds to higher

$167 I^{2}$ index values.

Multilevel meta-analysis including type of cheese and pasteurized or unpasteurized milk

169 were used to account for some of the observed between-study variance in prevalence data. 
with $\left(X_{1}\right.$ to $\left.X_{k}\right)$ being study characteristics and $\beta_{k}$ the moderator effects.

Meta-analysis modelling was performed by using R version 3.1.3 (R Development Core Team) and the "metafor" package (Viechtbauer, 2010), which provides functions for fitting of random-effects and multilevel models as well as meta-analytical graphs including forest plots.

\subsection{Regression modelling}

A linear regression model $(y=a+b x)$ was used to evaluate the relation between prevalence of Listeria spp. (x) and prevalence of L. monocytogenes (y). Regression modelling was performed with $\mathrm{R}$ and an F-test was used to evaluate if the linear model could be reduced to $y=b x$.

\section{Results}

\subsection{Meta-analysis of prevalence data from scientific literature}

The overall prevalence for presence of L. monocytogenes in cheese was $2.3 \%$ (CI: $1.4-$ 3.8\%). Variability in reported prevalence among studies was high (Table 6 and Fig.1) and the between-study variance slightly decrease from $\tau^{2}=1.72$ to 1.12 when cheeses were grouped in categories by the multilevel model. Nevertheless, unexplained variability remained high $\left(\mathrm{I}^{2}=75 \%\right.$; p-value $<0.001$ in Table 6).

Fresh cheese had the lowest mean prevalence of $0.8 \%$ (CI: $0.3-1.9 \%)$, followed by ripened cheese $2.0 \%$ (CI: $0.8-4.9 \%$ ), veined cheese $2.4 \%$ (CI: 0.9- 6.3\%) and smear cheese $5.1 \%$ (CI: 1.9 13.1\%). Brined cheese had the highest L. monocytogenes prevalence of $11.8 \%$ (CI: 3.5-33.3\%) (Table 6 and Fig. 1).

\subsection{Meta-analysis of prevalence data from EFSA reports}


The overall prevalence for presence of $L$. monocytogenes in cheese was $0.7 \%$ (CI: $0.5-$ 1.1\%) with high between-studies variance (Table 7). A multilevel model determined the prevalence of L. monocytogenes in hard and soft/semi-soft cheeses produced from un-pasteurized or pasteurized milk. No significant effect of pasteurization $(p>0.05)$ was observed within hard or soft/semi-soft cheeses (Table 7).

A second random-effects meta-analysis was performed to assess non-compliance with the criterion of $100 \mathrm{cfu} / \mathrm{g}$ for L. monocytogenes in ready-to-eat (RTE) foods. $0.2 \%$ (CI: $0.1-0.4)$ of the cheese samples had more than 100 L. monocytogenes/g and high between-study variance was observed (Table 8). Prevalence of L. monocytogenes in hard and soft/semi-soft cheese produced with un-pasteurized or pasteurized milk was estimated. Pasteurization of milk had no significant effect $(p>0.05)$ within hard or soft/semi-soft cheeses (Table 8).

\subsection{Meta-analysis of combined prevalence data from scientific literature and EFSA reports}

The overall prevalence of L. monocytogenes in European cheeses was 1.2\% (CI: $0.8-1.8 \%$ ). High between-study variance was observed and a significant difference $(p<0.001)$ was determined between data from the scientific literature and from EFSA reports data (Table 9).

\subsection{Evaluation of index organisms for prevalence of L. monocytogenes in European cheeses}

Of 3852 samples reporting presence of Listeria spp., 203 (5.3\%) were positive for $L$. monocytogenes, $327(8.5 \%)$ L. innocua, 19 (0.5\%) L. grayi, 188 (4.9\%) L. welshimer, 18 (0.5\%) L. ivanovii and $20(0.5 \%)$ L. seeligeri. The correlation factor was sufficient to describe the relation between prevalence of Listeria spp. (x) and prevalence of L. monocytogenes $(\mathrm{y})$ in cheeses $(\mathrm{y}=0.52$ $\mathrm{x}, \mathrm{r}^{2}=0.86$, Fig. 2).

\section{Discussion}


It is critical to understand and quantified prevalence of $L$. monocytogenes in cheeses since they are an important vehicle for transmission of the pathogen and infection causes the highest fatality case rate among zoonotic diseases (EFSA, 2016).

EU mean prevalence of $L$. monocytogenes in cheese from scientific literature exceeded what was reported by EFSA for the same period. This may result from a focus on problematic cheese products in scientific studies whereas EFSA reports include a larger number of samples from hard cheeses where L. monocytogenes can be inactivated and prevalence therefore is lower. The data from scientific studies corresponded to previous studies reporting prevalence between 0 and $4.8 \%$ (Esho et al., 2013; Manfreda et al., 2005; Rosengren et al., 2010), but some other studies reported more than 40\% prevalence (Loncarevic et al., 1995; Pintado et al., 2005).

Mean prevalence of L. monocytogenes in fresh cheese was similar to the overall prevalence obtained from EFSA data. In 1985 consumption of contaminated fresh cheese (queso blanco) was directly linked to more than 142 cases of listeriosis, including 48 deaths (Linnan et al., 1988). From 2009 to 2012 there was an outbreak in Portugal linked to 30 cases of listeriosis, including 11 deaths and related to consumption of fresh cheeses (curded cheese and queijo fresco) (Magalhães et al., 2015). Furthermore, Greco et al., (2014) for example demonstrated how prevalence of $L$. monocytogenes can be high $(24.4 \%)$ in mozzarella cheese as result of cross-contamination. Fresh cheeses were excluded from the EFSA baseline survey on prevalence of $L$. monocytogenes in certain RTE foods within EU during 2010-2011 (EFSA, 2013a). Interestingly, EFSA (2015) started to differentiate between fresh and soft/semi-soft cheeses but included only $2.1 \%$ fresh cheese samples compared to $80.1 \%$ hard cheese samples from a total of 13,718 cheese samples. Hard cheese have never been linked to a listeriosis outbreak (Table 1) and as it does not support growth of L. monocytogenes (Dalmasso \& Jordan, 2014; Wemmenhove et al.,2013; Yousef 
\& Marth, 1990) the large number of these samples does not correspond to a risk-based sampling approach.

It is important to note that mean prevalence for brined cheese was estimated from only four studies with smaller sample sizes compare with other types of cheese. Consequently, there is a high level of uncertainty and results may be biased by results from a single study (Fig. 1; Table 6). In 2012, Ricotta salata imported from Italy and contaminated with L. monocytogenes was involved in a listeriosis outbreak in the USA with 22 hospitalizations and 4 deaths (CDC, 2012). Furthermore, ricotta salata supports growth of L. monocytogenes (Coroneo et al., 2016; Spanu et al., 2012) and production of this cheese includes manual processing of the curd and exposure to processing environments that increase the risk of L. monocytogenes contamination (Spanu et al., 2013). Our findings suggest that prevalence of L. monocytogenes in fresh and brined cheese are not negligible; therefore we encourage EFSA to increase and independently report sampling of fresh and brined cheeses since they have been related with listeriosis outbreaks recurrently (Table 1).

As shown by EFSA reports, contamination of cheese by L. monocytogenes is not specific to un-pasteurized milk cheeses since cheeses made from pasteurized milk can be contaminated due to inadequate pasteurization or post-pasteurization contamination (De Buyser et al., 2001; Donnelly, 2001). Our report is the first of our knowledge to analysed EFSA prevalence data of cheeses made from un-pasteurized and pasteurized milk. There was no significant difference in prevalence between cheeses produced with un-pasteurized or pasteurized milk; either for hard or soft/semi-soft cheeses (Table 7 and 8). This may be due to requirements leading to the use of milk of high microbiological quality for the production of un-pasteurized milk cheese and to post-pasteurization contamination of pasteurized milk cheese. Tiwari et al., (2015) compared the risk of soft/semi-soft cheese made from un-pasteurized or pasteurized milk and estimated a higher risk for un-pasteurized milk cheese as a consequence of the higher contamination rate of milk due to the lack of 
pasteurization and growth of L. monocytogenes in un-pasteurized milk cheese but inactivation in the same pasteurized milk cheese. But this study observed no significant effect of pasteurization in prevalence of L. monocytogenes in soft/semi-soft cheese. We provide mean prevalence and distributions for L. monocytogenes in soft/semi-soft cheese that can be combined with concentration data of L. monocytogenes ( $\mathrm{cfu} / \mathrm{g}$ ) for the same period in un-pasteurized and pasteurized milk cheese to perform a quantitative risk assessment of the end product (Crépet et al., 2007) and results from both studies could be compared.

Prevalence and concentration of L. monocytogenes in cheeses are low, hence evaluation of potential presence of other index or indicator microorganisms easier to determine or quantify was considered. Listeria spp. has been proposed as index organisms for presence of L. monocytogenes in RTE foods and as indicator of inadequate hygiene conditions in food production practices and environment (FSAI, 2011; Gilbert et al., 2000; McLauchlin, 1997). These findings were confirmed by the present study and we found prevalence of $L$. monocytogenes corresponded to prevalence of Listeria spp. when multiplied by a factor of 0.52 . This was further supported by Trmčić et al., (2016) where 273 cheese samples had 12 positive for Listeria spp. and five of these positive for $L$. monocytogenes. Silva et al., (2003) also found 33\% of Listeria spp. positive samples from cheese and dairy processing plants to be L. monocytogenes positive. However, Arrese \& Arroyo-Izaga (2012) found no L. monocytogenes positive amongst 51 cheese samples with five samples positive for other Listeria spp. Microbiological methods for detection and quantification of Listeria spp. are not more performant than available methods for L. monocytogenes (Gasanov et al., 2005).

Therefore, we do not consider Listeria spp. a useful index- or indicator-organism L. monocytogenes despite the relation reported in the present study (Fig. 2).

\section{Conclusions}


Meta-analysis provided pooled prevalence estimates for L. monocytogenes in specific types of

287 cheeses, however, significant between-study variance was observed. Overall prevalence of $L$.

288 monocytogenes in cheese as estimated from scientific literature data was higher than reported by

289 data from EFSA during the same period 2005-2015. Considering prevalence of L. monocytogenes in 290 cheeses produced with un-pasteurized or pasteurized milk no significant difference in prevalence 291 was observed. The results obtained provided a broad picture of $L$. monocytogenes prevalence in 292 cheeses and can be used as an important input in quantitative microbial risk assessments. Listeria 293 spp. was not a useful index- or indicator-organism for L. monocytogenes in cheeses although 294 prevalence of Listeria spp. was related to prevalence of L. monocytogenes. 
Prevalence [ $95 \% \mathrm{Cl}$ ]

Reference

\section{Fresh}

Domenech et al., 2015

Parisi et al., 2013

Domenech et al., 2013

Dambrosio et al., 2013

Angelidis et al., 2012

Prencipe et al., 2010

Pesavento et al., 2010

Di Pinto et al., 2010

O'Briend et al., 2009

Mean incidence

\section{Brined}

Coroneo et al., 2016

Gyurova et al., 2014

Spanu et al., 2015

Filiousis et al., 2009

Mean incidence

\section{Smear}

lannetti et al., 2016 Schoder et al., 2015

Lambertz et al., 2012

Angelidis et al., 2012

Prencipe et al., 2010

O'Briend et al., 2009

Mean incidence

\section{Veined}

lannetti et al., 2016 Schoder et al., 2015

Gyurova et al., 2014

Lambertz et al., 2012

Angelidis et al., 2012

Prencipe et al., 2010

O'Briend et al., 2009

Mean incidence

\section{Ripened}

lannetti et al., 2016

Spanu et al., 2015

Schoder et al., 2015

Domenech et al., 2015

Gyurova et al., 2014

Prencipe et al., 2010

Little et al., 2009

Mean incidence

\section{RE Model}

lannetti et al., 2016

O'Briend et al., 2009

Filiousis et al., 2009

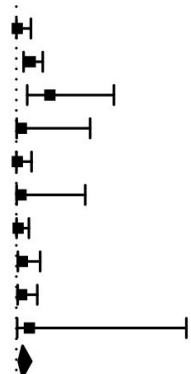

1
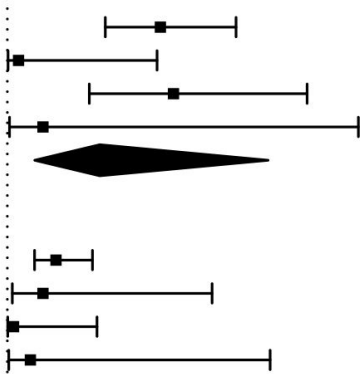

버
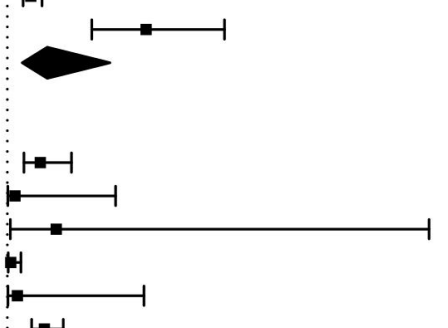

$\mathrm{H}=\mathrm{H}$
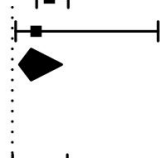

$+$
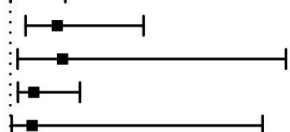

虾

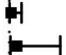

$-1$

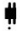
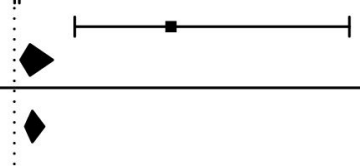

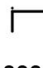

$0.001[0.000,0.019]$

$0.018[0.009,0.034$ ]

$0.043[0.014,0.125]$

$0.006[0.000,0.094$ ]

$0.001[0.000,0.019$ ]

$0.006[0.000,0.088$ ]

$0.002[0.000,0.016]$

0.008 [ $0.002,0.030$ ]

0.007 [ $0.002,0.027$ ]

$0.017[0.001,0.217$ ]

0.008 [ $0.003,0.019$ ]

$0.195[0.125,0.292]$

$0.014[0.001,0.191]$

$0.212[0.105,0.383$ ]

$0.045[0.003,0.448]$

0.118 [ $0.035,0.333$ ]

$0.062[0.035,0.109]$

$0.045[0.006,0.261]$

$0.008[0.000,0.115$ ]

$0.029[0.002,0.336$ ]

$0.030[0.020,0.044$ ]

$0.177[0.108,0.277$ ]

0.051 [ $0.019,0.131$ ]

$0.042[0.021,0.082]$

$0.010[0.001,0.138$ ]

$0.062[0.004,0.539$ ]

$0.004[0.001,0.017]$

$0.013[0.001,0.175$ ]

$0.047[0.031,0.071$ ]

$0.030[0.004,0.186]$

0.024 [ $0.009,0.063$ ]

$0.005[0.000,0.070]$

$0.060[0.019,0.170$ ]

$0.067[0.009,0.352]$

$0.030[0.010,0.089$ ]

$0.028[0.002,0.322]$

$0.002[0.000,0.016$ ]

$0.010[0.001,0.065]$

$0.002[0.000,0.006$ ]

$0.200[0.077,0.428]$

0.020 [ $0.008,0.049$ ]

0.023 [ $0.014,0.038$ ]

298 Fig. 1. Forest plot of the multilevel model based on scientific literature reporting prevalence of L. monocytogenes in 


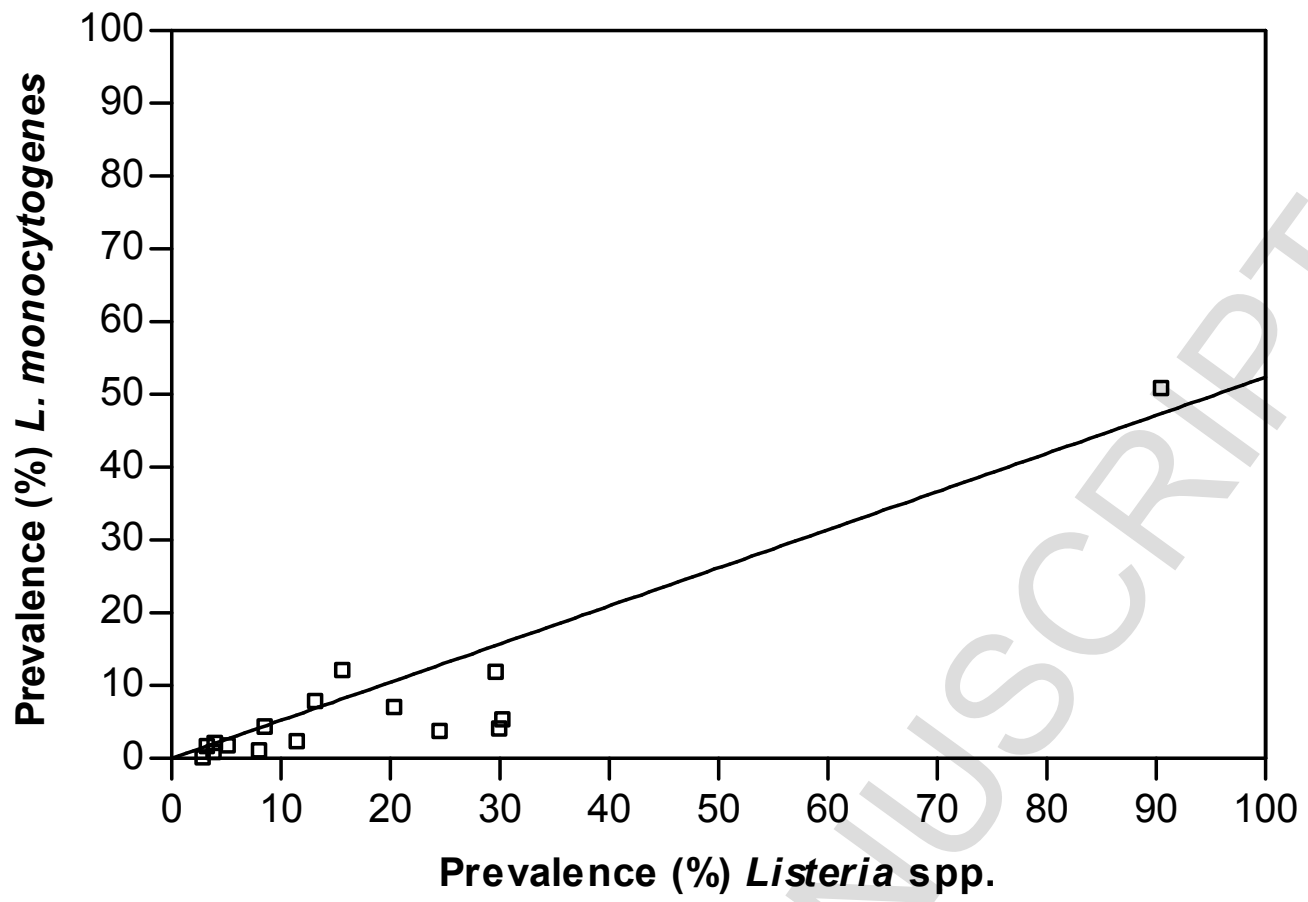

300

Fig. 2. Comparison of observed prevalence (\%) for Listeria spp. and L. monocytogenes in European cheeses.

302

303

304

305

306

307

308

309

310

311

312

313

314

315 
Table 1

Overview of listeriosis outbreaks caused by cheese during the period from 1983 to 2016.

\begin{tabular}{|c|c|c|c|c|c|}
\hline Country & Year & Serotype & $\begin{array}{l}\text { No. }{ }^{\text {a }} \text { of cases } \\
\text { (fatalities) }\end{array}$ & Implicated food & References \\
\hline Switzerland & $1983-1987$ & $4 b$ & $122(31)$ & $\begin{array}{l}\text { Smear cheese } \\
\text { (Vacherin Mont d'Or) }\end{array}$ & $\begin{array}{l}\text { Büla et al., 1995; } \\
\text { Bille et al., } 2006\end{array}$ \\
\hline USA & 1985 & $4 b$ & $142(48)$ & $\begin{array}{l}\text { Fresh cheese } \\
\text { (Queso Fresco) }\end{array}$ & Linnan et al., 1988 \\
\hline Luxembourg & 1989 & $\mathrm{NR}^{\mathrm{b}}$ & $2(0)$ & $\begin{array}{l}\text { Smear cheese } \\
\text { (Camembert) }\end{array}$ & Ries et al., 1990 \\
\hline Denmark & $1989-1990$ & $4 b$ & $26(6)$ & Veined or ripened cheese & Jensen et al., 1994 \\
\hline France & 1995 & $4 b$ & $37(11)$ & $\begin{array}{l}\text { Smear cheese } \\
\text { (Brie de Meaux) }\end{array}$ & $\begin{array}{l}\text { Goulet et al., 1995; } \\
\text { Arnold \& Coble, } \\
1995\end{array}$ \\
\hline France & 1997 & $4 b$ & $14\left(?^{\mathrm{c}}\right)$ & $\begin{array}{l}\text { Smear cheese } \\
\text { (Pont l'Evêque) }\end{array}$ & $\begin{array}{l}\text { Ryser \& Marth, } \\
2007 \text {; Goulet et al., } \\
2013\end{array}$ \\
\hline USA & 2000 & $4 b$ & $13(5)$ & $\begin{array}{l}\text { Non-commercial fresh } \\
\text { cheese } \\
\text { (Queso Fresco) }\end{array}$ & $\begin{array}{l}\text { MacDonald et al., } \\
2005\end{array}$ \\
\hline Sweden & 2001 & $1 / 2 \mathrm{a}$ & $\geq 120(0)$ & Fresh cheese & $\begin{array}{l}\text { Carrique-Mas et } \\
\text { al., 2003; } \\
\text { Danielsson-Tham } \\
\text { et al., } 2004\end{array}$ \\
\hline Japan & 2001 & $1 / 2 b$ & $38(0)$ & Smear cheese & Makino et al., 2005 \\
\hline Canada & 2002 & $4 b$ & $47(0)$ & Soft and semi-soft cheese & Gaulin et al., 2003 \\
\hline Canada & 2002 & $4 b$ & $86(0)$ & $\begin{array}{l}\text { Cheese made from } \\
\text { pasteurized milk }\end{array}$ & Pagotto et al., 2006 \\
\hline Switzerland & 2005 & $1 / 2 \mathrm{a}$ & $10\left(3+2^{d}\right)$ & $\begin{array}{l}\text { Smear cheese } \\
\text { (Soft "Tomme") }\end{array}$ & Bille et al., 2006 \\
\hline USA & 2005 & $\mathrm{NR}^{\mathrm{b}}$ & & $\begin{array}{l}\text { Fresh cheese } \\
\text { (Queso fresco) }\end{array}$ & FIOD, 2005 \\
\hline Czech Republic & 2006 & & $78(13)$ & Soft cheese & EFSA, 2007 \\
\hline Germany & $2006-2007$ & $4 \mathrm{~b}$ & $189(26)$ & Acid curd cheese & Koch et al., 2010 \\
\hline Norway & 2007 & $\mathrm{NR}^{\mathrm{b}}$ & $17(3)$ & $\begin{array}{l}\text { Smear cheese } \\
\text { (Camembert) }\end{array}$ & Johnsen et al., 2010 \\
\hline Chile & 2008 & $\mathrm{NR}^{\mathrm{b}}$ & $91(5)$ & $\begin{array}{l}\text { Smear cheese } \\
\text { (Brie) }\end{array}$ & Promed, 2008 \\
\hline Canada & 2008 & $\mathrm{NR}^{\mathrm{b}}$ & $38(5)$ & Cheeses & $\begin{array}{l}\text { Gaulin \& Ramsay, } \\
2010\end{array}$ \\
\hline USA & 2008 & $1 / 2 \mathrm{a}$ & $8(0)$ & $\begin{array}{l}\text { Fresh cheese } \\
\text { (Oaxaca cheese) }\end{array}$ & Jackson et al., 2011 \\
\hline $\begin{array}{l}\text { Austria-Germany- } \\
\text { Czech Republic }\end{array}$ & 2009-2010 & $1 / 2 \mathrm{a}$ & $34(8)$ & $\begin{array}{l}\text { Fresh cheese } \\
\text { (Quargel) }\end{array}$ & $\begin{array}{l}\text { Fretz et al., 2010; } \\
\text { Rychli et al., } 2014\end{array}$ \\
\hline Portugal & 2009- 2012 & $4 b$ & $30(11)$ & $\begin{array}{l}\text { Fresh cheese } \\
\text { (Cured cheese and queijo } \\
\text { fresco) }\end{array}$ & $\begin{array}{l}\text { Magalhães et al., } \\
2015\end{array}$ \\
\hline USA & 2010 & $\mathrm{NR}^{\mathrm{b}}$ & $5(0)$ & $\begin{array}{l}\text { Fresh cheese } \\
\text { (Panela, queso fresco, } \\
\text { Requeson) }\end{array}$ & FIOD, 2010 \\
\hline USA & $2010-2015$ & $\mathrm{NR}^{\mathrm{b}}$ & $28(3)$ & Fresh cheeses & FIOD, 2015b \\
\hline
\end{tabular}




\begin{tabular}{|c|c|c|c|c|c|}
\hline USA & 2011 & $\mathrm{NR}^{\mathrm{b}}$ & $2\left(?^{c}\right)$ & $\begin{array}{l}\text { Fresh cheese } \\
\text { (Chives cheese) }\end{array}$ & FIOD, 2011 \\
\hline Austria-Germany & 2011-2013 & $1 / 2 b$ & $7\left(?^{c}\right)$ & Fresh cheese & Schmid et al., 2014 \\
\hline Spain & 2012 & $1 / 2 \mathrm{a}$ & $2(0)$ & $\begin{array}{l}\text { Fresh cheese } \\
\text { (Queso fresco) }\end{array}$ & $\begin{array}{l}\text { De Castro et al., } \\
2012\end{array}$ \\
\hline USA & 2012 & $\mathrm{NR}^{\mathrm{b}}$ & $22(4)$ & $\begin{array}{l}\text { Brined cheese } \\
\text { (Ricotta salatta) }\end{array}$ & $\begin{array}{l}\text { CDC, 2012; } \\
\text { Coroneo et al., } \\
2016\end{array}$ \\
\hline USA & 2013 & $\mathrm{NR}^{\mathrm{b}}$ & $5(1)$ & $\begin{array}{l}\text { Smear cheese } \\
\text { (Les Freres) }\end{array}$ & FIOD, 2013 \\
\hline Australia & 2013 & $\mathrm{NR}^{\mathrm{b}}$ & $18\left(?^{\mathrm{c}}\right)$ & Smear cheese & \\
\hline USA & $2013-2014$ & $\mathrm{NR}^{\mathrm{b}}$ & $4(1)$ & Fresh cheese & FIOD, 2014a \\
\hline USA & 2014 & $\mathrm{NR}^{\mathrm{b}}$ & $7(1)$ & Fresh cheese & FIOD, 2014b \\
\hline USA & 2015 & $\mathrm{NR}^{\mathrm{b}}$ & $3(1)$ & $\begin{array}{l}\text { Fresh cheese } \\
\text { (Panela, Queso Fresco, } \\
\text { Requeson, Cotija) }\end{array}$ & FIOD, 2015b \\
\hline
\end{tabular}

${ }^{a}$ Number of listeriosis cases

${ }^{\mathrm{b}}$ Serotype not reported (NR)

${ }^{\mathrm{c}}$ Fatalities uncertain

${ }^{d}$ Septic abortion i.e. fatality

Table 2

Prevalence data $(\mathrm{s} / \mathrm{n})$ from the scientific literature.

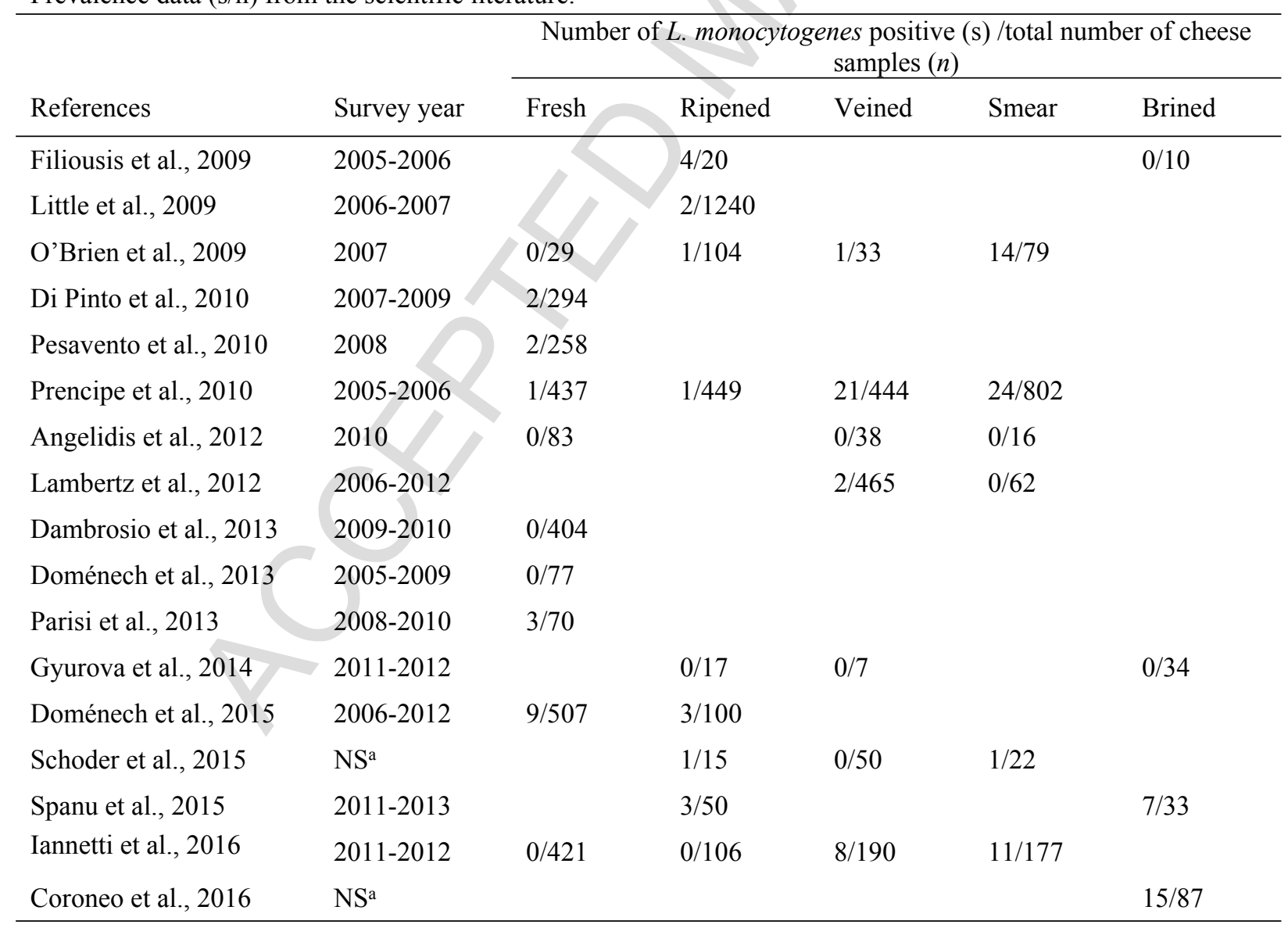


Total

$17 / 2,580$

$15 / 2,101$

$32 / 1,218$

$50 / 1,158$

$24 / 164$

a Not specified; but assumed within the period 2005-2015.

Table 3

Prevalence data ( $\mathrm{s} / \mathrm{n})$ from EFSA reports.

\begin{tabular}{|c|c|c|c|c|c|c|c|c|}
\hline \multicolumn{2}{|c|}{ Type of cheese } & \multicolumn{7}{|c|}{ Number of L. monocytogenes positive (s)/total number of cheese samples ( $n$ ) } \\
\hline & & $\begin{array}{l}\text { EFSA, } \\
2006^{a}\end{array}$ & $\begin{array}{l}\text { EFSA, } \\
2007^{a}\end{array}$ & $\begin{array}{l}\text { EFSA, } \\
2009^{a}\end{array}$ & $\begin{array}{l}\text { EFSA, } \\
2010^{a}\end{array}$ & $\begin{array}{l}\text { EFSA, } \\
2011^{a}\end{array}$ & $\begin{array}{l}\text { EFSA, } \\
2015^{a}\end{array}$ & $\begin{array}{l}\text { EFSA, } \\
2016^{a}\end{array}$ \\
\hline & & $2005^{b}$ & $2006^{b}$ & $2007^{b}$ & $2008^{b}$ & $2009^{b}$ & $2013^{b}$ & $2015^{b}$ \\
\hline \multirow[b]{2}{*}{ Hard } & $\begin{array}{l}\text { Un- } \\
\text { pasteurized }\end{array}$ & 0/969 & $38 / 718$ & $16 / 3,242$ & $2 / 1,606$ & $2 / 1,001$ & $15 / 1,618$ & $11 / 858$ \\
\hline & Pasteurized & $0 / 1,367$ & $5 / 3,284$ & $68 / 9,449$ & $85 / 10,877$ & $15 / 7,246$ & $77 / 8,288$ & $19 / 2,384$ \\
\hline \multirow{2}{*}{$\begin{array}{l}\text { Soft/ } \\
\text { Semi-soft }\end{array}$} & $\begin{array}{l}\text { Un- } \\
\text { pasteurized }\end{array}$ & $29 / 1,505$ & $13 / 1,959$ & $16 / 5,943$ & $5 / 4,203$ & $6 / 774$ & $155 / 2,880$ & 10/707 \\
\hline & Pasteurized & $25 / 5,973$ & $22 / 4,736$ & $853 / 16,333$ & $70 / 5,585$ & $41 / 4,087$ & $49 / 10,668$ & $67 / 5,123$ \\
\hline
\end{tabular}

${ }^{a}$ References

${ }^{\mathrm{b}}$ Survey year

Table 4

Cheese samples in non-compliance with EU food safety limits for L. monocytogenes in RTE foods.

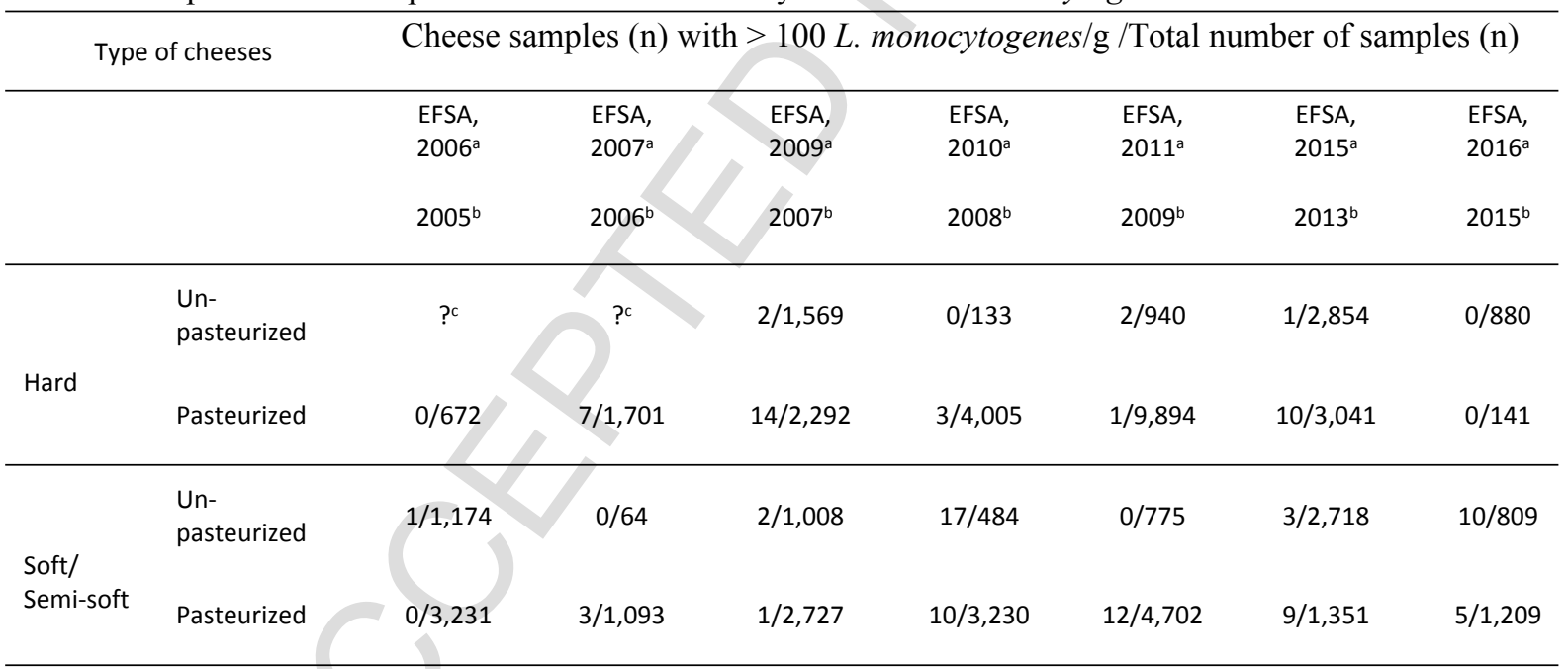

b Survey year

c Not reported 
Table 5

European studies reporting the prevalence of Listeria species in cheeses.

\begin{tabular}{|c|c|c|c|c|c|c|c|c|}
\hline \multirow{2}{*}{ References } & \multirow{2}{*}{ Country } & \multirow{2}{*}{$\begin{array}{l}\text { Sample } \\
\text { size }\end{array}$} & \multicolumn{6}{|c|}{ Number of samples positive for different Listeria species } \\
\hline & & & $\begin{array}{c}\text { L. } \\
\text { monocytogenes }\end{array}$ & $\begin{array}{c}L . \\
\text { innocua }\end{array}$ & $\begin{array}{l}L . \\
\text { grayi }\end{array}$ & $\begin{array}{c}\text { L. } \\
\text { welshimer }\end{array}$ & $\begin{array}{l}L . \\
\text { ivanovii }\end{array}$ & $\begin{array}{c}\text { L. } \\
\text { seeligeri }\end{array}$ \\
\hline Comi et al., 1990 & Italy & 1740 & 65 & 145 & 15 & 185 & 18 & 0 \\
\hline Massa et al., 1990 & Italy & 121 & 2 & 2 & 0 & 0 & 0 & 0 \\
\hline Quagilo et al., 1992 & Italy & 246 & 29 & 42 & 0 & 0 & 0 & 2 \\
\hline Rota et al., 1992 & Spain & 58 & 1 & 2 & 0 & 0 & 0 & 0 \\
\hline Pinto \& Reali, 1996 & Italy & 132 & 7 & 30 & 0 & 2 & 0 & 1 \\
\hline $\begin{array}{l}\text { Theodoridis et al., } \\
1998\end{array}$ & Greece & 334 & 26 & 8 & & 0 & 0 & 10 \\
\hline Bottarelli et al., 1999 & Italy & 100 & 2 & 2 & 0 & 0 & 0 & 0 \\
\hline $\begin{array}{l}\text { Rudolf \& Scherer, } \\
2000\end{array}$ & Germany & 50 & 2 & 13 & 0 & 0 & 0 & 0 \\
\hline $\begin{array}{l}\text { Rudolf \& Scherer, } \\
2001\end{array}$ & Austria & 274 & 19 & 33 & 0 & 0 & 0 & 4 \\
\hline Vitas et al., 2004 & Spain & 99 & 1 & 6 & 1 & 0 & 0 & 0 \\
\hline Pintado et al., 2005 & Portugal & 63 & 32 & 23 & 0 & 0 & 0 & 2 \\
\hline Pesavento et al., 2010 & Italy & 258 & 2 & 6 & 1 & 1 & 0 & 0 \\
\hline Angelidis et al., 2012 & Greece & 137 & 0 & 1 & 2 & 0 & 0 & 1 \\
\hline Parisi et al., 2013 & Italy & 70 & 3 & 3 & 0 & 0 & 0 & 0 \\
\hline Schoder et al., 2015 & Europe & & 2 & 8 & 0 & 0 & 0 & 0 \\
\hline Spanu et al., 2015 & Italy & 83 & 10 & 3 & 0 & 0 & 0 & 0 \\
\hline Total & & 3,852 & 203 & 327 & 19 & 188 & 18 & 20 \\
\hline
\end{tabular}


Table 6

Meta-analysis results for prevalence of L. monocytogenes from scientific literature

\begin{tabular}{lllll}
\hline Meta-analysis type & Prevalence $(\mathrm{CI})^{\mathrm{a}}$ & $\tau^{2 \mathrm{~b}}$ & $\mathrm{I}^{2}(\%)^{\mathrm{c}}$ & $\mathrm{Q}^{\mathrm{d}}$ \\
\hline Random-effects & $0.023(0.014-0.038)$ & 1.72 & 86 & $197^{* * * \mathrm{e}}$ \\
& & & & $(\mathrm{df}=35)$ \\
& & 1.12 & 75 & $108^{* * * \mathrm{e}}$ \\
Multilevel & $0.008(0.003-0.019)^{\mathrm{Af}}$ & & & $(\mathrm{df}=31)$ \\
Fresh cheese & $0.020(0.008-0.049)^{\mathrm{ABf}}$ & & & \\
Ripened cheese & $0.024(0.009-0.063)^{\mathrm{Bf}}$ & & & \\
Veined cheese & $0.051(0.019-0.131)^{\mathrm{Bf}}$ & & & \\
Smear cheese & $0.118(0.035-0.333)^{\mathrm{Bf}}$ & & & \\
Brined cheese & & & & \\
\hline
\end{tabular}

a $95 \%$ confidence interval.

367 b Between-study variance.

${ }^{c}$ Between-study variance index proposed by Higgins \& Thompson (2002).

${ }^{\mathrm{d}}$ Q-statistic proposed by DerSimonian \& Laird (1986).

e P-value $<0.001$.

${ }^{\mathrm{f}}$ Mean values for classes with the same capital letter do not differ significantly $(p>0.05)$.

Table 7

Meta-analysis results for prevalence of L. monocytogenes from EFSA reports

\begin{tabular}{llccc}
\hline Meta-analysis type & Prevalence $(\mathrm{CI})^{\mathrm{a}}$ & $\tau^{2 \mathrm{~b}}$ & $\mathrm{I}^{2}(\%)^{\mathrm{c}}$ & $\mathrm{Q}^{\mathrm{d}}$ \\
\hline Random-effects & $0.007(0.005-0.011)$ & 1.09 & 98 & $1712^{* * * \mathrm{e}}$ \\
& & & & $(\mathrm{df}=27)$ \\
Multilevel & & 1.17 & 88 & $1174^{* * * \mathrm{e}}$ \\
& & & $(\mathrm{df}=24)$ \\
Hard and un-pasteurized & $0.006(0.003-0.015)^{\mathrm{f}}$ & & \\
Hard and pasteurized & $0.012(0.002-0.010)^{\mathrm{f}}$ & & \\
Soft/semi-soft and un-pasteurized & $0.009(0.004-0.019)^{\mathrm{g}}$ & & & \\
Soft/semi-soft and pasteurized & $0.010(0.004-0.022)^{\mathrm{g}}$ & & & \\
\hline
\end{tabular}

a $95 \%$ confidence interval.

${ }^{\mathrm{b}}$ Between-study variance.

${ }^{\mathrm{c}}$ Between-study variance index proposed by Higgins \& Thompson (2002).

${ }^{\mathrm{d}}$ Q-statistic proposed by DerSimonian \& Laird (1986).

380 e P-value $<0.001$.

$381 \quad{ }^{\mathrm{f}}$ Mean values within hard cheeses do not differ significantly $(p>0.05)$.

${ }^{\mathrm{g}}$ Mean values within soft/semi-soft cheeses do not differ significantly $(p>0.05)$. 
Table 8

Meta-analysis results assessing non-compliance with the criterion of "> $100 \mathrm{cfu} / \mathrm{g}$ " for L. monocytogenes in cheeses as reported by EFSA.

\begin{tabular}{ll}
\hline Meta-analysis type & Prevalence $(\mathrm{CI})^{\mathrm{a}}$ \\
\hline Random-effects & $0.002(0.001-0.004)$ \\
& \\
Multilevel & \\
Hard and un-pasteurized & $0.001(0.000-0.004)^{\mathrm{f}}$ \\
Hard and pasteurized & $0.002(0.001-0.005)^{\mathrm{f}}$ \\
Soft/semi-soft and un-pasteurized & $0.004(0.002-0.012)^{\mathrm{g}}$ \\
Soft/semi-soft and pasteurized & $0.002(0.001-0.006)^{\mathrm{g}}$ \\
\hline
\end{tabular}

a $95 \%$ confidence interval.

b Between-study variance.

${ }^{c}$ Between-study variance index proposed by Higgins \& Thompson (2002).

d Q-statistic proposed by DerSimonian \& Laird (1986).

e P-value $<0.001$.

${ }^{\mathrm{f}}$ Mean values within hard cheeses do not differ significantly $(p>0.05)$.

g Mean values within soft/semi-soft cheeses do not differ significantly $(p>0.05)$.

Table 9

Meta-analysis results for prevalence of $L$. monocytogenes from combined data

\begin{tabular}{lllll}
\hline Meta-analysis type & Prevalence $(\mathrm{CI})^{\mathrm{a}}$ & $\tau^{2 \mathrm{~b}}$ & $\mathrm{I}^{2}(\%)^{\mathrm{c}}$ & $\mathrm{Q}^{\mathrm{d}}$ \\
\hline Random-effects & $0.012(0.008-0.018)$ & 1.78 & 97 & $1961^{* * * \mathrm{e}}$ \\
& & & & $(\mathrm{df}=63)$ \\
Multilevel & & 1.38 & 97 & $\begin{array}{l}1909 * * * \mathrm{e} \\
(\mathrm{df}=62)\end{array}$ \\
Scientific literature & $0.007(0.004-0.011)^{\mathrm{Af}}$ & & & \\
EFSA reports & $0.024(0.015-0.038)^{\mathrm{Bf}}$ & & & \\
\hline
\end{tabular}

a $95 \%$ confidence interval.

$\mathrm{b}$ Between-study variance.

c Between-study variance index proposed by Higgins \& Thompson (2002).

${ }^{\mathrm{d}}$ Q-statistic proposed by DerSimonian \& Laird (1986).

e P-value $<0.001$.

${ }^{\mathrm{f}}$ Mean values for classes with different capital letters differed significantly $(p<0.001)$. 
425 426 427 428 429

430 431 432 433 434 435 436 437 438 439

440

441 442 443 444 445 446 447 448 449 30

\section{Acknowledgements}

The present study was supported by DTU Food and by Danish Veterinary and Food Administration.

27 We thank Dr. Ursula Gonzales-Barron from Instituto Politécnico de Bragança, Portugal for advice on $\mathrm{R}$ code to performed forest plot. 
450

451

452

453

454

455

456

457

458

459

460

461

462

463

464

465

466

467

468

469

470

471

472

473

474

475

476

477

478

479

480

481

\section{References}

Angelidis, A. S., Georgiadou, S. S., Zafeiropoulou, V., Velonakis, E. N., Papageorgiou, D. K., \& Vatopoulos, A. (2012). A survey of soft cheeses in Greek retail outlets highlights a low prevalence of Listeria spp. Dairy Science and Technology, 92(2), 189-201.

Arnold, G. J., \& Coble, J. (1995). Incidence of Listeria species in foods in NSW. Food Australia, $47(2), 71-75$.

Arrese, E., \& Arroyo-Izaga, M. (2012). Prevalence of Listeria monocytogenes in Idiazabal cheese. Nutricion Hospitalaria, 27(6), 2139-2141.

Barron, U. G., Soumpases, I., Butler, F., Prendergast, D., Duggan, S., Duffy, G. (2009). Estimation of Prevalence of Salmonella on Pig Carcasses and Pork Joints, Using a Quantitative Risk Assessment Model Aided by Meta-Analysis. Journal of Food Protection, 72(2), 274-285.

Bille, J., Blanc, D. S., Schmid, H., Boubaker, K., Baumgartner, A., Siegrist, H. H., Tritten, M.L., Liernhard, R., Berner, D., Anderau, R., Treboux, M., Ducommun, J.M., Malinverni, R., Genné, D., Erard, P., \& Waespi, U. (2006). Outbreak of human listeriosis associated with Tomme cheese in Northwest Switzerland, 2005. Eurosurveillance, 11(6), 91-93.

Borenstein, M., Hedges, L. V., Higgins, J. P. T., \& Rothstein, H. R. (2009). Introduction to metaanalysis (1st ed.). Chichester: Willey.

Bottarelli, A., Bonardi, S., \& Bentley, S. (1999). Presence of Listeria spp. in short-ripened cheeses. Annali Della Facoltà Di Medicina Veterinaria, 29, 293-296.

Brodsky, M. H. (1995). The benefits and limitations of using index and indicator microorganisms in verifying food safety. Presented at the FSIS meeting on the "Role of microbiology testing in verifying food safety", May 1-2, 1995, Philadelphia, PA.

Büla, C. J., Bille, J., \& Glauser, M. P. (1995). An epidemic of food-borne listeriosis in western Switzerland: description of 57 cases involving adults. Clinical Infectious Diseases, 20(1), 6672.

CAC (2013). Codex General Standard for Cheese. CODEX STAN 283-1978 www.fao.org/input/download/standards/175/CXS_283e.pdf Accessed 13.05.16

Carrique-Mas, J. J., Hökeberg, I., Andersson, Y., Arneborn, M., Tham, W., Danielsson-Tham, M. L., Osterman, B., Leffler, M., Steen, M., Eriksson, E., Hedin, G., \& Giesecke, J. (2003). Febrile gastroenteritis after eating on-farm manufactured fresh cheese--an outbreak of listeriosis? Epidemiology and Infection, 130(1), 79-86.

CDC (2012). Centers for Disease Control and Prevention. Multistate outbreak of listeriosis linked to 
imported Frescolina Marte brand ricotta salata. https://www.cdc.gov/listeria/outbreaks/cheese09-12/ Accessed 23.03.17.

Cochran, W. G. (1954). The combination of estimates from different experiments. Biometrics, 10(1), 101-129.

Comi, G., Cantoni, C., Valenti, M., \& Civilini, M. (1990). Listeria species in Italian cheeses. Microbiologie Aliments Nutrition, 8, 377-382.

Condoleo, R., Mezher, Z., Marozzi, S., Guzzon, A., Fischetti, R., Senese, M., Sette, S., \& Bucchini, L. (2016). Risk assessment of human listeriosis from semisoft cheeses made from raw sheep's milk in Lazio and Tuscany (Italy). Risk Analysis. http://doi.org/10.1111/risa.12649

Coroneo, V., Carraro, V., Aissani, N., Sanna, A., Ruggeri, A., Succa, S., Meloni, B., Pinna, A., \& Sanna, C. (2016). Detection of Virulence Genes and Growth potential in Listeria monocytogenes strains isolated from Ricotta salata cheese. Journal of Food Science, 81(1), M114-M120.

Crepet, A., Albert, I., Dervin, C., \& Carlin, F. (2007). Estimation of microbial contamination of food from prevalence and concentration data: Application to Listeria monocytogenes in fresh vegetables. Applied and Environmental Microbiology, 73(1), 250-258.

Cummins, A. J., Fielding, A. K., \& McLauchlin, J. (1994). Listeria ivanovii infection in a patient with AIDS. Journal of Infection, 28(1), 89-91.

Dalmasso, M., \& Jordan, K. (2014). Absence of growth of Listeria monocytogenes in naturally contaminated Cheddar cheese. Journal of Dairy Research, 81(1), 46-53.

Dambrosio, A., Quaglia, N. C., Saracino, M., Malcangi, M., Montagna, C., Quinto, M., Lorusso, V., \& Normanno, G. (2013). Microbiological quality of Burrata cheese produced in Puglia Region: Southern Italy. Journal of Food Protection, 76(11), 1981-1984.

Danielsson-Tham, M.-L., Eriksson, E., Helmersson, S., Leffler, M., Ludtke, L., Steen, M., Sørgjerd, S., \& Tham, W. (2004). Causes behind a human cheese-borne outbreak of gastrointestinal listeriosis. Foodborne Pathogens and Disease, 1(3), 153-159.

De Buyser, M.-L., Dufour, B., Maire, M., \& Lafarge, V. (2001). Implication of milk and milk products in food-borne diseases in France and in different industrialised countries. International Journal of Food Microbiology, 67(1-2), 1-17.

de Castro, V., Escudero, J. M., Rodriguez, J. L., Muniozguren, N., Uribarri, J., Saez, D., \& Vazquez, J. (2012). Listeriosis outbreak caused by Latin-style fresh cheese, Bizkaia, Spain, August 2012. Eurosurveillance, 17(42), 3-5. 
DerSimonian, R., \& Laird, N. (1986). Meta-analysis in clinical trials. Controlled Clinical Trials, 7(3), 177-188.

Di Pinto, A., Novelleo, L., Montemurro, F., Bonerba, E., \& Tantillo, G. (2010). Occurrence of Listeria monocytogenes in ready-to-eat foods from supermarkets in Southern Italy. New Microbiologica, 33(3), 249-252.

Doménech, E., Amorós, J. A., \& Escriche, I. (2013). Effectiveness of prerequisites and the HACCP plan in the control of microbial contamination in ice cream and cheese companies. Foodborne Pathogens and Disease, 10(3), 222-8.

Doménech, E., Jimenez -Belenguer, A., Amoros, J. A., Ferrus, M. A., \& Escriche, I. (2015). Prevalence and antimicrobial resistance of Listeria monocytogenes and Salmonella strains isolated in ready-to-eat foods in Eastern Spain. Food Control, 47, 120-125.

Donnelly, C. W. (2001). Factors associated with hygienic control and quality of cheeses prepared from raw milk: a review. Bulletin of the International Dairy Federation, 369, 16-27.

DTU Findit. Technical University of Denmark digital library (2017). https://findit.dtu.dk/ Accessed 05.04.17.

EFSA. (2006). The community summary report on trends and sources of zoonoses, zoonotic agents, antimicrobial resistance and foodborne outbreaks in the European Union in 2006. EFSA Journal, 94, 1-288.

EFSA. (2007). The Community Summary Report on Trends and Sources of Zoonoses, Zoonotic Agents, Antimicrobial resistance and Foodborne outbreaks in the European Union in 2006. EFSA Journal, 130 , 1-352.

EFSA. (2009). Trends and sources of zoonoses and zoonotic agents in the European Union in 2007. EFSA Journal, 223, 1-320.

EFSA. (2010). Trends and sources of zoonoses and zoonotic agents and food-borne outbreaks in the European Union in 2008. EFSA Journal, 8(1), 1-368.

EFSA. (2011). The European Union summary report on trends and sources of zoonoses, zoonotic agents and food-borne outbreaks in 2009. EFSA Journal, 9(3), 1-378.

EFSA. (2013a). Analysis of the baseline survey on the prevalence of Listeria monocytogenes in certain ready-to-eat foods in the EU, 2010-2011 Part A: Listeria monocytogenes prevalence estimates. EFSA Journal, 11(6), 3241.

EFSA. (2013b). The European Union summary report on trends and sources of zoonoses, zoonotic agents and food-borne outbreaks in 2011. EFSA Journal, 11(4), 1-250. 
EFSA. (2015). The European Union summary report on trends and sources of zoonoses, zoonotic agents and food-borne outbreaks in 2013. EFSA Journal, 13(1), 3991.

EFSA. (2016). The Euroean Union summary report on trends and sources of zoonsoes, zoonotic agents and food-borne outbreaks in 2015. EFSA Journal, 14(14), 4634.

Esho, F. K., Enkhtuya, B., Kusumoto, A., \& Kawamoto, K. (2013). Microbial Assessment and Prevalence of Foodborne Pathogens in Natural Cheeses in Japan. BioMed Research International, 2013:20580, 1-6. http://doi.org/10.1155/2013/205801

EU Regulation (EC) N0. 2073/2005. Commission Regulation (EC) N0. 2073/2005 of 15 November 2005 on microbiological criteria for foodstuffs. Official Journal of the European Communitites, 338(2073), 1-26.

FDA. (2015). Joint FDA / Health Canada quantitative assessment of the risk of listeriosis from softripened cheese consumption in the United States and Canada: Report. https://www.fda.gov/downloads/Food/FoodScienceResearch/RiskSafetyAssessment/UCM429 419.pdf Accessed 10.03.16.

Filiousis, G., Johansson, A., Frey, J., \& Perreten, V. (2009). Prevalence, genetic diversity and antimicrobial susceptibility of Listeria monocytogenes isolated from open-air food markets in Greece. Food Control, 20(3), 314-317.

Finazzi, G., Daminelli, P., Serraino, A., Pizzamiglio, V., Riu, R., Giacometti, F., Bertasi, B., Losio, M.N., \& Boni, P. (2011). Behaviour of Listeria monocytogenes in packaged water buffalo mozzarella cheese. Letters in Applied Microbiology, 53(3), 364-370.

FIOD (2005). Raw, unpasteurized, queso fresco 2005. http://www.outbreakdatabase.com/details/raw-unpasteurized-queso-fresco2005/?organism=Listeria + monocytogenes\&vehicle=cheese Accessed 29.05.16 FIOD. (2010). Queseria Bendita Fresh Cheese 2010. http://www.outbreakdatabase.com/details/queseria-bendita-fresh-cheese2010/?organism=Listeria + monocytogenes\&vehicle $=$ cheese Accessed 29.05.16

FIOD. (2011). Green Cedar Dairy - Harb, Inc. Natural Ackawi and Chives Cheese 2011. http://www.outbreakdatabase.com/details/green-cedar-dairy-harb-inc.-natural-ackawi-andchives-cheese-2011/?organism=Listeria + monocytogenes\&vehicle=cheese Accessed 29.05.16. FIOD. (2013). Les Freres Cheese Listeriosis Outbreak, June 2013. http://www.outbreakdatabase.com/details/les-freres-cheese-listeriosis-outbreak-june2013/?organism $=$ Listeria + monocytogenes $\&$ vehicle $=$ cheese Accessed 29.05.16 
FIOD. (2014a). 2013-2014 Listeria linked to Oasis Brands Cheese. http://www.outbreakdatabase.com/details/2013-2014-listeria-linked-to-oasis-brandscheese/?organism=Listeria + monocytogenes\&vehicle=cheese Accessed 29.05.16.

FIOD. (2014b). 2014 Outbreak of Listeriosis Linked to Soft Cheese Produced by Roos Foods. http://www.outbreakdatabase.com/details/2014-outbreak-of-listeriosis-linked-to-soft-cheeseproduced-by-roos-foods/?organism $=$ Listeria + monocytogenes\&vehicle $=$ cheese Accessed 29.05.16

FIOD. (2015a). 2015 Listeria Outbreak Linked to Queseria Bendita Latin-style cheese, Washington State. http://www.outbreakdatabase.com/details/2015-listeria-outbreak-linked-to-queseriabendita-latin-style-cheese-washingtonstate/?organism $=$ Listeria + monocytogenes\&vehicle $=$ cheese Accessed 29.05.16

FIOD. (2015b). Listeriosis linked to soft cheese produced by Karoun Dairies, Inc., 2010 to 2015. http://www.outbreakdatabase.com/details/listeriosis-linked-to-soft-cheese-produced-bykaroun-dairies-inc.-2010-to-2015/?organism=Listeria + monocytogenes\&vehicle $=$ cheese Accessed 29.05.16

Fox, P.F., Guinee, T.P., Cogan, T.M., \& McSweeney, P.L.H. (2000). Fundamentals of cheese science. (1st ed.). Maryland: Aspen, (Chapter 17).

Fretz, R., Pichler, J., Sagel, U., Much, P., Ruppitsch, W., Pietzka, A. T., Stöger, A., Huhulescu, S., Hueberger, S., Appl, G., Werber, D., Stark, K., Prager, R., Flieger, A., Karpísková, R., Pfaff, G., \& Allerberger, F. (2010). Update: Multinational listeriosis outbreak due to "quargel", a sour milk curd cheese, caused by two different L. monocytogenes serotype 1/2a strains, 20092010. Eurosurveillance, 15(16), 2-3.

FSAI. (2011). Establishing baseline data on the presence of Listeria monocytogenes on cooked meat slicers in retail and catering. https://www.fsai.ie/establishingbaselinedataonthepresenceoflisteriamonocytogenesoncookedm eatslicersinretailandcateringpremises.html Accessed 10.05.17

FSIS. (2014). FSIS Compliance Guideline: Controlling Listeria monocytogenes in post-lethality exposed ready-to-eat meat and poultry products. https://www.fsis.usda.gov/wps/wcm/connect/d3373299-50e6-47d6-a577e74a1e549fde/Controlling-Lm-RTE-Guideline.pdf?MOD=AJPERES Accessed 25.04.16.

Gasanov, U., Hughes, D., \& Hansbro, P. M. (2005). Methods for the isolation and identification of Listeria spp. and Listeria monocytogenes: a review. Fems Microbiology Reviews, 29(5), 851- 
610

611

612

613

614

615

616

617

618

619

620

621

622

623

624

625

626

627

628

629

630

631

632

633

634

635

636

637

638

639

640

641

875.

Gaulin, C. (2003). First documented outbreak of Listeria monocytogenes in Quebec, 2002. Canada Communicable Disease Report = Relevé Des Maladies Transmissibles Au Canada, 29(21), 181-186.

Gaulin, C., \& Ramsay, D. (2010). Le lien suivant vous amènera à un autre site Web Rapport d'investigation et d'intervention à la suite de l'éclosion d'infections à Listeria monocytogenes pulsovar 93 liée à la consommation de fromages québecois, 2008.

https://www.mapaq.gouv.qc.ca/fr/Publications/Rapporteclosionlisteriose.pdf Accessed 08.06.16.

Gianfranceschi, M. V., Rodriguez-Lazaro, D., Hernandez, M., González-García, P., Comin, D., Gattuso, A., Delibato, E., Sonnessa, M., Pasquali, F., Prencipe, V., Sreter-Lancz, Z., SaizAbajo, M.J., Pérez-De-Juan, J., Butrón, J., Kozačinski, L., Tomic, D.H., Zdolec, N., Johannessen, G.S., Jakočiüne, D., Olsen, J.E., De Santis, P., Lovari, S., Bertasi, B., Pavoni, E., Paiusco, A., De Cesare, A., Manfreda, G., \& De Medici, D. (2014). European validation of a real-time PCR-based method for detection of Listeria monocytogenes in soft cheese. International Journal of Food Microbiology, 184, 128-133.

Gilbert, R. J., de Louvois, J., Donovan, T., Little, C., Nye, K., Ribeiro, C. D., Richards, J., Roberts, D., \& Bolton, F. J. (2000). Guidelines for the microbiological quality of some ready-to-eat foods sampled at the point of sale. PHLS Advisory Committee for Food and Dairy Products. Communicable Disease and Public Health, 3(3), 163-167.

Glass, G. V. (1976). Primary, secondary, and meta-analysis of research. Educational Researcher, 5(10), 3-8.

Greco, S., Tolli, R., Bossù, T., Flores Rodas, E. M., Di Giamberardino, F., Di Sirio, A., Vita, S., De Angelis, V., Bilei, S., Sonnessa, M., Gattuso, A., \& Lanni, L. (2014). Case of contamination by Listeria monocytogenes in mozzarella cheese. Italian Journal of Food Safety, 3(1), 51-53.

Goulet, V., Jacquet, C., Vaillant, V., Rebière, I., Mouret, E., Lorente, C., Maillot, E., Staïner, F., \& Rocourt, J. (1995). Listeriosis from consumption of raw-milk cheese. The Lancet, 345(8964), 1581-1582.

Goulet, V., King, L. A., Vaillant, V., \& de Valk, H. (2013). What is the incubation period for listeriosis? BMC Infectious Diseases, 13, 11. doi:10.1186/1471-2334-13-11.

Gyurova, E., Krumova-Vulcheva, G., Daskalov, H., \& Gogov, Y. (2014). Prevalence of Listeria monocytogenes in ready-to-eat foods in Bulgaria. Journal of Hygienic Engineering and 
Design, 7, 112-118. UDC 579.67:579.869.1.

Higgins, J. P. T., \& Thompson, S. G. (2002). Quantifying heterogeneity in a meta-analysis. Statistics in Medicine, 21(11), 1539-1558.

Iannetti, L., Acciari, V. A., Antoci, S., Addante, N., Bardasi, L., Bilei, S., Calistri, P., Cito, F., Cogoni, P., D'Aurelio, R., Decastelli, L., Iannetti, S., Iannito, G., Marino, A.M.F., Muliari, R., Neri, D., Perilli, M., Pomilio, F., Prencipe, V.A., Proroga, Y., Santarelli, G.A., Sericola, M., Torresi, M., \& Migliorati, G. (2016). Listeria monocytogenes in ready-to-eat foods in Italy: Prevalence of contamination at retail and characterisation of strains from meat products and cheese. Food Control, 68, 55-61.

Jackson, K. A., Biggerstaff, M., Tobin-D’Angelo, M., Sweat, D., Klos, R., Nosari, J., Garrison, O., Boothe, E., Saathoff-Huber, L., Hainstock, L., \& Fagan, R. P. (2011). Multistate outbreak of Listeria monocytogenes associated with Mexican-style cheese made from pasteurized milk among pregnant, Hispanic women. Journal of Food Protection, 74(6), 949-953.

Jensen, A., Frederiksen, W., \& Gerner-Smidt, P. (1994). Risk Factors for Listeriosis in Denmark, 1989-1990. Scandinavian Journal of Infectious Diseases, 26(2), 171-178.

Johnsen, B. O., Lingaas, E., Torfoss, D., Strøm, E. H., \& Nordøy, I. (2010). A large outbreak of Listeria monocytogenes infection with short incubation period in a tertiary care hospital. Journal of Infection, 61(6), 465-470.

Koch, J., Dworak, R., Prager, R., Becker, B., Brockmann, S., Wicke, A., Wichmann-Schauer, H., Hof, H., Werber, D., \& Stark, K. (2010). Large listeriosis outbreak linked to cheese made from pasteurized milk, Germany, 2006-2007. Foodborne Pathogens and Disease, 7(12), 15811584.

Lambertz, S. T., Nilsson, C., Brådenmark, a, Sylvén, S., Johansson, a, Jansson, L.-M., \& Lindblad, M. (2012). Prevalence and level of Listeria monocytogenes in ready-to-eat foods in Sweden 2010. International Journal of Food Microbiology, 160(1), 24-31.

Linnan, M. J., Mascola, L., Lou, X. D., Goulet, V., May, S., Salminen, C., Hird, D.W., Yonekura, M.L., Hayes, P., Weaver, R., Audurier, A., Plikaytis, B.D., Fannin, S.L., Kleks, A., \& Broome, C. V. (1988). Epidemic listeriosis associated with Mexican-style cheese. New England Journal of Medicine, 319(13), 823-828.

Little, C. L., Sagoo, S. K., Gillespie, I. A., \& Grant, K. (2009). Prevalence and level of Listeria monocytogenes and other Listeria species in selected retail ready-to-eat foods in the United Kingdom. Journal of Food Protection, 72(9), 1869-1877. 
Loncarevic, S., Danielsson-Tham, M. L., \& Tham, W. (1995). Occurrence of Listeria monocytogenes in soft and semi-soft cheeses in retail outlets in Sweden. International Journal of Food Microbiology, 26(2), 245-250.

MacDonald, P.D., Whitwam, R.E., Boggs, J.D., MacCormack, J.N., Anderson, K.L., Reardon, J.W., Saah, J.R., Graves, L.M., Hunter, S.B., \& Sobel, J. (2005). Outbreak of listeriosis among Mexican immigrants as a result of consumption of illicitly produced Mexican-style cheese. Clinical Infectious Diseases, 40(5), 677-682.

Magalhães, R., Almeida, G., Ferreira, V., Santos, I., Silva, J., Mendes, M. M., Pita, J., Mariano, G., Mancio, I., Sousa, M.M., Farber, J., Pagotto, F., \& Teixeira, P. (2015). Cheese-related listeriosis outbreak, Portugal, March 2009 to February 2012. Eurosurveillance, 20(17), 1-6.

Makino, S. I., Kawamoto, K., Takeshi, K., Okada, Y., Yamasaki, M., Yamamoto, S., \& Igimi, S. (2005). An outbreak of food-borne listeriosis due to cheese in Japan, during 2001. International Journal of Food Microbiology, 104(2), 189-196.

Massa, S., Cesaroni, D., Poda, G., \& Trovatelli, L. D. (1990). The incidence of Listeria spp . in soft cheeses, butter and raw milk in the province of Bologna. Journal of Applied Bacteriology, 68(2), 153-156.

McLauchlin, J. (1997). The identification of Listeria species. International Journal of Food Microbiology, 38(1), 77-81.

Mossel, D. A. . (1978). Index and indicator organisms - a current assessment of their usefulness and significance. Food Technology in Australia, 30, 212-219.

NSW. (2013). Further Cases of Listeria Identified. http://www.health.nsw.gov.au/news/Pages/20130118_01.aspx Accessed 15.06.16.

O’Brien, M., Hunt, K., McSweeney, S., \& Jordan, K. (2009). Occurrence of foodborne pathogens in Irish farmhouse cheese. Food Microbiology, 26(8), 910-914.

OXOID. (2016). Listeria Precis. http://www.oxoid.com/pdf/uk/27363_Listeria_Precis.pdf Accessed 20.05.16.

Pagotto, F., Ng, L.-K., Clark, C., \& Farber, J. (2006). Canadian listeriosis reference service. Foodborne Pathogens and Disease, 3(1), 132-137.

Parisi, A., Latorre, L., Fraccalvieri, R., Miccolupo, A., Normanno, G., Caruso, M., \& Santagada, G. (2013). Occurrence of Listeria spp. in dairy plants in Southern Italy and molecular subtyping of isolates using AFLP. Food Control, 29(1), 91-97.

Pesavento, G., Ducci, B., Nieri, D., Comodo, N., \& Lo Nostro, A. (2010). Prevalence and antibiotic 
susceptibility of Listeria spp. isolated from raw meat and retail foods. Food Control, 21(5), $708-713$.

Pintado, C. M. B. ., Oliveira, A., Pampulha, M. E., \& Ferreira, M. A. S. (2005). Prevalence and characterization of Listeria monocytogenes isolated from soft cheese. Food Microbiology, 22(1), 79-85.

Pinto, B., \& Reali, D. (1996). Prevalence of Listeria monocytogenes and other listerias in Italianmade soft cheeses. International Journal of Hygiene and Environmental Medicine, 199(1), 198.

Prencipe, V., Migliorati, G., Matteucci, O., Calistri, P., \& Giannatale, E. Di. (2010). Valutazione della qualità igienico sanitaria di alcuni tipi di formaggi prelevati in fase di vendita al dettaglio. Veterinaria Italiana, 46(2), 221-231.

ProMed. (2008). Listeriosis, fatal - Chile: (Santiago), cheese suspected, request for information. http://www.promedmail.org/post/20081128.3754 Accessed 10.06.16.

Quaglio, G., Casolari, C., Menziani, G., \& Fabio, A. (1992). Indagine sulla presenza di Listeria monocytogenes in campioni di latte e derivati. L'Igiene Moderna, 97, 565-579.

Ries, F. (1990). Camembert, Listeria and the immunocompromised patient. Bulletin De La Societe Des Sciences Medicales Du Grand-Duche De Luxembourg, 127(1), 41-43.

Rocourt, J., Hof, H., Schrettenbrunner, A., Malinverni, R., \& Bille, J. (1986). Acute purulent Listeria seelingeri meningitis in an immunocompetent adult. Schweizerische Medizinische Wochenschrift, 116(8), 248-251.

Rodriguez-Lazaro, D., Gonzalez-García, P., Gattuso, A., Gianfranceschi, M. V., \& Hernandez, M. (2014). Reducing time in the analysis of Listeria monocytogenes in meat, dairy and vegetable products. International Journal of Food Microbiology, 184, 98-105.

Rosengren, Å., Fabricius, A., Guss, B., Sylvén, S., \& Lindqvist, R. (2010). Occurrence of foodborne pathogens and characterization of Staphylococcus aureus in cheese produced on farm-dairies. International Journal of Food Microbiology, 144(2), 263-269.

Rota, C., Yangüela, J., Blanco, D., Carramiñana, J. J., \& Herrera, A. (1992). Aislamiento e identificación de microorganismos del G. Listeria en quesos frescos, quesos curados y quesos fundidos. Alimentaria, 236, 59-62.

Rudolf, M., \& Scherer, S. (2000). Incidence of Listeria and Listeria monocytogenes in acid curd cheese. Archiv Für Lebensmittelhygiene, 51, 81-128.

Rudolf, M., \& Scherer, S. (2001). High incidence of Listeria monocytogenes in European red smear 
cheese. International Journal of Food Microbiology, 63(1-2), 91-98.

Rychli, K., Müller, A., Zaiser, A., Schoder, D., Allerberger, F., Wagner, M., \& Schmitz-Esser, S. (2014). Genome sequencing of Listeria monocytogenes "Quargel” listeriosis outbreak strains reveals two different strains with distinct in vitro virulence potential. PLOS ONE, 9(2), 1-11.

Ryser, E. T., \& Marth, E. H. (2007). Foodborne Listeriosis. In Listeria, listeriosis, and food safety. (3th ed.). Boca Raton: CRC Press, (Chapter 10).

Sanaa, M., Coroller, L., \& Cerf, O. (2004). Risk assessment of listeriosis linked to the consumption of two soft cheeses made from raw milk: Camembert of Normandy and Brie of Meaux. Risk Analysis, 24(2), 389-399.

Sargeant, J. M., Amezcua, M., Rajic, A., \& Waddell, L. (2005). A guide to condacting systematic reviews in agri-food public health. http://www.angelfire.com/co4/civph/english.pdf Accessed 22.10.15.

Schmid, D., Allerberger, F., Huhulescu, S., Pietzka, A., Amar, C., Kleta, S., Prager, R., Preußel, K., Aichinger, E., \& Mellmann, A. (2014). Whole genome sequencing as a tool to investigate a cluster of seven cases of listeriosis in Austria and Germany, 2011-2013. Clinical Microbiology and Infection, 20(5), 431-436.

Schoder, D., Strauß, A., Szakmary-Brändle, K., \& Wagner, M. (2015). How safe is European Internet cheese? A purchase and microbiological investigation. Food Control, 54, 225-230.

Silva, I. M. M., Almeida, R. C. C., Alves, M. A. O., \& Almeida, P. F. (2003). Occurrence of Listeria spp. in critical control points and the environment of Minas Frescal cheese processing. International Journal of Food Microbiology, 81(3), 241-248.

Spanu, C., Scarano, C., Spanu, V., Penna, C., Virdis, S., \& De Santis, E. P. L. (2012). Listeria monocytogenes growth potential in Ricotta salata cheese. International Dairy Journal, 24(2), $120-122$.

Spanu, C., Spanu, V., Pala, C., Virdis, S., Scarano, C., \& De Santis, E. P. L. (2013). Evaluation of a post-lethality treatment against Listeria monocytogenes on Ricotta salata cheese. Food Control, 30(1), 200-205.

Spanu, C., Scarano, C., Ibba, M., Spanu, V., \& De Santis, E. P. L. (2015). Occurrence and traceability of Listeria monocytogenes strains isolated from sheep's milk cheese-making plants environment. Food Control, 47, 318-325.

Sutton, A. J. (2001). An illustrated guide to the methods of meta-analysis. Journal of Evaluation in Clinical Practice, 7(2), 135-148. 
Theodoridis, A., Abrahim, A., Sarimvei, A., Panoulis, C., Karaioannoglou, P. Genigeorgis, C., \& A., M. (1998). Prevalence and significance of Listeria monocytogenes in Greek whey cheeses . A comparison between the years 1990 and 1996. MILCHWISSENSCHAFT, 53(3), 147-149.

Tiwari, U., Cummins, E., Valero, A., Walsh, D., Dalmasso, M., Jordan, K., \& Duffy, G. (2015). Farm to fork quantitative risk assessment of Listeria monocytogenes contamination in raw and pasteurized milk cheese in Ireland. Risk Analysis, 35(6), 1140-1153.

Trmčić, A., Chauhan, K., Kent, D. J., Ralyea, R. D., Martin, N. H., Boor, K. J., \& Wiedmann, M. (2016). Coliform detection in cheese is associated with specific cheese characteristics, but no association was found with pathogen detection. Journal of Dairy Science, 99(8), 6105-6120.

Viechtbauer, W. (2010). Conducting meta-analyses in R with the metafor. Journal of Statistical Software, 36(3), 1-48.

Vitas, A. I., Aguado, V., \& Garcia-Jalon, I. (2004). Occurrence of Listeria monocytogenes in fresh and processed foods in Navarra (Spain). International Journal of Food Microbiology, 90(3), 349-356.

Web of Science.Thomson reuters (2017). https://webofknowledge.com/ Accessed 05.04.17.

Weller, D., Andrus, A., Wiedmann, M., \& den Bakker, H. C. (2015). Listeria booriae sp. nov. and Listeria newyorkensis sp. nov., from food processing environments in the USA. International Journal of Systematic and Evolutionary Microbiology, 65(Pt 1), 286-292.

Wemmenhove, E., Stampelou, I., van Hooijdonk, A. C. M., Zwietering, M. H., \& Wells-Bennik, M. H. J. (2013). Fate of Listeria monocytogenes in Gouda microcheese: No growth, and substantial inactivation after extended ripening times. International Dairy Journal, 32(2), 192-198.

Xavier, C., Gonzales-Barron, U., Paula, V., Estevinho, L., \& Cadavez, V. (2014). Meta-analysis of the incidence of foodborne pathogens in Portuguese meats and their products. Food Research International, 55, 311-323.

Yousef, A. E., \& Marth, E. H. (1990). Fate of Listeria monocytogenes During the Manufacture and Ripening of Parmesan Cheese. Journal of Dairy Science, 73(12), 3351-3356. 


\section{Highlights:}

- Overview of listeriosis outbreaks caused by cheese 1983-2016

- Overall prevalence of L. monocytogenes in European cheese 2005 - 2015

- Prevalence of $L$. monocytogenes in different types of cheese

- No indicator or index organism identified for $L$. monocytogenes in cheese 